\title{
Urban regeneration in Mediterranean cities: an integrated urban development of Brownfield sites
}

\author{
A. El Menchawy \\ Arab Academy for Science and Technology, Alexandria, Egypt
}

\begin{abstract}
Regeneration is an organic metaphor concerned with improving the economic, social and environmental vitality of the city. It brings new life to previously run down areas, refurbishing buildings, infrastructure and the built environment, and redeveloping buildings that have reached the end of their useful life. Many Mediterranean cities have already launched such operations (Barcelona, Genoa), while respecting historical and uniqueness of each case.

The paper integrates two main issues; the first describes the main features of urban regeneration, analyse its process in Mediterranean cities. Many of these cities in recent decades experienced redevelopment for new "postindustrial uses" often related to culture, tourism, and technology. Such uses may offer the potential for creating more sustainable and livable cities, especially in old industrial areas.

The second issue describes urban regeneration in three Mediterranean cities, (Genoa, Barcelona, and Alexandria). Genoa was taken as a first case study for restructuring the old harbour areas, the waterfront and historic centre. At present Genoa has regained a new identity and its role in the Italian system. The second case study is Barcelona that was influenced through its transformation by organising the Olympic Games of 1992. It is now one of the most successful cities in the world for its innovative urban planning. It has survived the economic, environmental and social changes through focusing upon its culture background, urban transformation, establishing magnet projects, urban and equity management, and waterfront development. Finally, Alexandria was taken as a local case study. The city development strategy, CDS, enable Alexandria to take advantage of its competitive endowments, better manage local assets, and remove constraints for a private sector-led growth, while ensuring the socioeconomic integration of the poor, improve the living conditions of its residents, and prevent further deterioration. The project starts since 2004, leading to a number of new projects that provide economic benefits, while focusing on environmental improvement, slum upgrading, and ensure that it moves towards its regeneration.
\end{abstract}

Keywords: urban regeneration, urban development, Mediterranean cities, Brownfield sites. 


\section{Introduction}

The existing urban structure in the Mediterranean region is characterised by two prominent features: existence of old historic ports; and orientation of the urban life towards the sea. In order to maintain this typical character of the Mediterranean cities, it is necessary to launch the process of urban regeneration. The studies cover a variety of urban situations in the coastal regions of the Mediterranean that is characterised by strong urbanisation, particularly along its coasts. From 94 million inhabitants located in Mediterranean urban centers in the middle of the 20th century, expected to reach 378 million in 2025 (Mediterranean Commission for Sustainable Development). By the year 2025, more than 7 inhabitants out of 10 will probably be living in an urban centre in coastal Mediterranean region.

\subsection{Definition of urban regeneration}

The concept of urban regeneration is to promote a "return to the city", revitalise the city centre, and improve the quality of the environment operating towards a smart growth. It was first formalised in the U.S.A. in the $1960 \mathrm{~s}$, when relocation of marine activities. In the 1980s, a second phase was launched in Barcelona. It leads to the complete transformation of Brownfield sites, through reconstruction of multi-activity. Later, in the 1990s, it was launched in many urban areas, often densely populated. There may be three reasons why urban regeneration is taking place: severe living conditions; investors are looking for available land for big projects (e.g. Barcelona); deterioration of social and economic fabrics (e. g. Aleppo, Alexandria). An urban regeneration process can start under a combination of factors as: a strategic view to guide the process; political support and commitment; organisational framework; financing; mapping of the existing problems and opportunities; requires a gradual development; and maintaining the process.

The developed of urban regeneration is shown in table 1.

\subsection{Mediterranean urban degradation}

Most Mediterranean cities have high rates of population growth, immigration towards coastal cities, and increased urbanisation rate. However, there is also lack of respect for traditions; increased violence; growing social polarisation; inequalities in consumption patterns and income...etc. Environmental conditions are worsening with increasing demands on resources (e.g. water, soil and energy) leading to degradation of ecosystems and landscapes, increasing air pollution and loss of open spaces. Within cities, there is a, high densities and land values, but also limited public financial resources. The following problems can reflect urban degradation as shown in table 2 . Such problems create physical, environmental, economic and social hazards are becoming more difficult to resolve, demanding urban regeneration and development of Brownfield sites. 
Table 1: Development of urban regeneration.

\begin{tabular}{|l|l|l|}
\hline \multicolumn{1}{|c|}{ Urban forms } & \multicolumn{1}{c|}{ year } & \multicolumn{1}{c|}{ Urban criteria } \\
\hline Reconstruction & $1950 \mathrm{~s}$ & Physical changes of older areas on 'master plan' \\
\hline Revitalisation & $1960 \mathrm{~s}$ & Structural changes that has some social objectives \\
\hline Renewal & $1970 \mathrm{~s}$ & Focused on neighborhood schemes \\
\hline Redevelopment & $1980 \mathrm{~s}$ & Focused on major projects including social objectives \\
\hline Regeneration & $1990 \mathrm{~s}$ & $\begin{array}{l}\text { A comprehensive form of policy and practice with } \\
\text { integrated actions on the urban fabric [14]. }\end{array}$ \\
\hline
\end{tabular}

Source: Lichfield [2], modified by researcher.

Table 2: $\quad$ Mediterranean urban degradation.

\begin{tabular}{|l|l|}
\hline Degradation & \multicolumn{1}{c|}{ Features } \\
\hline Differences & Differences between the cities of the North and South \\
\hline Economic & Unemployment, poor foreign investments, decline of city centers \\
\hline Social & Poverty, deteriorating, conflicts, violence and segregation \\
\hline $\begin{array}{l}\text { Spatial and } \\
\text { Land Use }\end{array}$ & $\begin{array}{l}\text { High-density residential areas, illegal residential development, } \\
\text { dense urban cores, under-utilized urban land on waterfront and } \\
\text { harbor areas, declined industrial areas, disorganised spaces around } \\
\text { city entrance }\end{array}$ \\
\hline Environmental & $\begin{array}{l}\text { Air and sound pollution, destruction of cultural sites, degradation } \\
\text { of urban landscape and natural environments, hazardous to public } \\
\text { health }\end{array}$ \\
\hline Institutional & $\begin{array}{l}\text { Outdated urban management framework, poor implementation, } \\
\text { overlapping responsibilities }\end{array}$ \\
\hline Urban Sprawl & $\begin{array}{l}\text { Fast sprawl outward over brownfield and hinterlands, consumption } \\
\text { of land, separation between dwelling and workplace }\end{array}$ \\
\hline Infrastructures & $\begin{array}{l}\text { Deteriorating infrastructure networks, lacking maintenance, } \\
\text { untreated waste water; lack of sanitation networks, unavailability } \\
\text { of mass transportation, traffic jams in old town districts. }\end{array}$ \\
\hline Slum Areas & Unplanned squatters, dwellings are over-populated \\
\hline Technology & Poor transfer of technology in southern Mediterranean \\
\hline
\end{tabular}

Source: researcher.

\subsection{Brownfield sites development}

Urban development has evolved from a simple form of renovation of infrastructure and built-up land, to target restructuring of the urban fabric, and renewal of city image. It takes place in specific scenes in old industrial areas, harbor areas, waterfronts, that proposed integration between new and existing functions and activities, creating new centers that can modify the hierarchies inside the city. Urban development of Brownfield sites doesn't mean for a city only expanding or renewing, but rather reuniting itself with own destiny, which was rooted in the past, be modified, starting from present condition [7]. The process starts by the following objectives, as shown in table 3 . 
Table 3: $\quad$ Objectives of Brownfield sites development.

\begin{tabular}{|l|l|}
\hline \multicolumn{1}{|c|}{ Criteria } & \multicolumn{1}{c|}{ Objectives } \\
\hline Economic & $\begin{array}{l}\text { Attracting investors, create employment, restructure economic } \\
\text { activities, develop new business opportunities }\end{array}$ \\
\hline Social & Enlarge the supply of urban housing and upgrade infrastructure \\
\hline Environmental & Improve living conditions, combat pollution \\
\hline Cultural & Architectural heritage, urban tourism, attract academic institutions \\
\hline $\begin{array}{l}\text { Urban } \\
\text { Management }\end{array}$ & $\begin{array}{l}\text { Preserving valuable fabric; control deterioration of urban zones, } \\
\text { rehabilitation of complex urban structures; slowdown urban spread } \\
\text { by creation of green belts, and redirecting growth towards new } \\
\text { towns, reorganising the urban shape, developing mass } \\
\text { transportation system. }\end{array}$ \\
\hline
\end{tabular}

Source: researcher.

\subsection{Urban regeneration and development strategies}

Each city's must resolve its own difficulties, respect its own social fabric, memory, heritage, and enhance its traditional and new potentials. Strategies must be applied by the combination of several objectives:

- In unregulated areas, the focus must be improvement infrastructure network.

- In urban zones, the goal is preservation and enhancement of inhabited traditions, attract urban tourism, construct cultural buildings, restore networks, create pedestrian areas, maintain traditional businesses, and introduce service activities.

- The control of land is a mandatory aspect to cover through enforced regulations

- Public participation provide city's characteristics, problems, prospects, needs, priorities, vision, commitment, and generate funding for project implementation.

\section{Case studies}

\subsection{Genoa, Italy}

Genoa is located on the north side of the Mediterranean Sea in Italy fig.1. It is the capital of Genova province and the centre of Italian Riviera, located on the Gulf of Genoa. The city is a narrow, densely occupied city with 650,000 inhabitants, and $240 \mathrm{~km}^{2}$ lies on a $22 \mathrm{~km}$ long, with a narrow coastal plain $9 \mathrm{~km}$, located between the sea and hills. The city can be divided into three parts: the centre, a concentration of cultural and historical heritage, was established, principal services, activities, and public offices. The western part is the location of industrial activities, while the eastern part has a residential function. The city has suffered loss of residents; change of composition, because of the steeply declined traditional industry. 

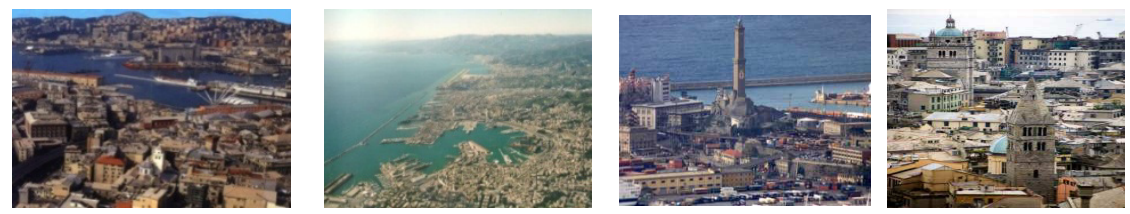

Figure 1: $\quad$ Existing pictures for Genoa.

\subsubsection{Genoa urban degradation}

A lot of problems had faced Genoa regeneration; the high urban density, isolation of historical centre from the newer parts of the city, noise and visual barriers between the city and the sea, growing traffic, insufficient street lighting, dumping garbage in the streets, high levels of unemployment, poor housing and environmental conditions, insufficient facilities and public services, criminality, the narrowness and bad condition of streets paving and pedestrian walkways, insufficient support of new businesses, inadequate parking and public transportation, bad access to traffic in the historical centre.

\subsubsection{Genoa urban regeneration plan}

In 1999 the Operating Plan for Historic City Centre preserve the historic values, with less physical, social and economical decay, together with more safety and cleanliness, bringing the new perception of Genoa as a port, tourist and cultural city using the splendid old part of the city, connecting it with the sea, and restoring significant architectural heritage. The city was first refurbished in 1992 to mark the Columbus anniversary celebration, new buildings was added; the unique Aquarium, the expo, the World Trade Centre, exhibition hall, conventions, conferences, and the Opera House. The underground is extended to connect the harbor and the main train stations. The city growth depends on the limited space bordered by the sea and the mountains. A complete waterfront renewal takes place, converting the industrial port and brownfields, into new urban spaces. The urban regeneration plan includes $[2,5,6]$ :

- Improvement of master-plan, coordinating precise projects into strategy;

- Support and create positive conditions for locals and tourists;

- Improved structures in the commercial port for common leisure and activities;

- Regeneration a new residential suburb in the west side of the city;

- $\quad$ Stop urban sprawl and promote neighborhood housing measures;

- Enhancement the social and economic features of the city centre;

- Regenerate the historical city centre;

- Achieve an adequate accessibility and mobility system;

- Enhance services for citizens;

- $\quad$ Promote physical integration between the city centre and the old harbor;

- Extend the city centre towards the sea;

- Strengthening transportation systems by connecting ports, railway, and subway; 
- Implementation investments, managing and setting of urban spaces in the port area;

- $\quad$ Promoting the characteristic of the coasts in the waterfront and the port area;

- Renew industrial suburb and promote social housing;

- Pedestrian accessibility to city centre by pavement and street renewal.

Table 4 shows Genoa urban regeneration strategies [10,13,14].

Table 4: Genoa urban regeneration strategies.

\begin{tabular}{|l|l|}
\hline \multicolumn{1}{|c|}{ Strategy } & \multicolumn{1}{c|}{ Criteria } \\
\hline $\begin{array}{l}\text { Waterfront } \\
\text { Redevelopment }\end{array}$ & $\begin{array}{l}\text { Renzo Piano renovates the port area, with beautiful walks, venues } \\
\text { for festivals, panoramic elevator, multi-theatre complex, and } \\
\text { aquarium. Waterfront stretches in the sea with artificial islands: } \\
\text { port terminals, shipyards, new airport, marinas, fishing port, and a } \\
\text { great park [13,17]. }\end{array}$ \\
\hline $\begin{array}{l}\text { Historic City } \\
\text { Centre }\end{array}$ & $\begin{array}{l}\text { Represent the cultural image of the city and become the hub of its } \\
\text { tourist, providing the historic city centre with new services; green } \\
\text { spaces, sport areas, schools, university centers, social services, } \\
\text { street paving, technological networks, luxury housing sector; new } \\
\text { pedestrian links, and parking areas. }\end{array}$ \\
\hline Port & $\begin{array}{l}\text { Located on the coastal mountains, extending 20 km along the } \\
\text { coast, fig.2, at the city's historic centre, with 13 terminals linked } \\
\text { to transportation networks, located over seven million square } \\
\text { meter, and offers connections to 120 countries. }\end{array}$ \\
\hline Transportation & $\begin{array}{l}\text { A new railway link the port to the great European network, new } \\
\text { terminals and a long tunnel under mountains were constructed, } \\
\text { and ferry terminals were renewed. }\end{array}$ \\
\hline $\begin{array}{l}\text { Creating new } \\
\text { spaces }\end{array}$ & $\begin{array}{l}\text { The city created spaces by digging hills, and reclaiming land, } \\
\text { building terraces and filling the sea; the port, the airport lies on } \\
\text { artificial soil. }\end{array}$ \\
\hline Business centre & Transforming old industrial area into a modern Business Centre. \\
\hline Funding & The organisation of big events collects funds. \\
\hline $\begin{array}{l}\text { Industrial } \\
\text { Activities }\end{array}$ & $\begin{array}{l}\text { An ICT industry creates a hi-tech cluster on the mountain terraces } \\
\text { for production, research, education and housing. }\end{array}$ \\
\hline $\begin{array}{l}\text { Entertainment } \\
\text { Areas }\end{array}$ & $\begin{array}{l}\text { A canal and a park were built between the new port and the town, } \\
\text { with retired resort, a large marina, and new touristic areas were } \\
\text { established. }\end{array}$ \\
\hline
\end{tabular}
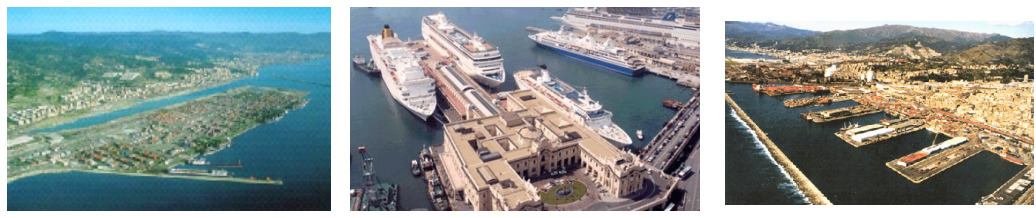

Figure 2: $\quad$ Genoa waterfront and port. 


\subsection{Barcelona, Spain}

\subsubsection{Introduction}

Barcelona is one of the most popular cities in Spain, the capital of Catalonia region. Its area is $485 \mathrm{~km}^{2}$; accommodate 2 million inhabitants, located between two rivers and two mountains. Its history stretch back over 2,000 years. It has architectural treasures from several periods. It hosts some of the world's greatest classical musicians, and contemporary theaters. It is the most cosmopolitan and economically active city in Spain. It is now widely recognised as one of the most successful cities in the world, for its innovative urban planning.

\subsubsection{Barcelona urban transformation}

Barcelona has a lot of urban problems; degradation and depopulation of the historical core, over-population in other districts, and uncontrolled urban expansion in the industrial area. Barcelona's growth was a result for the industrial revolution and the Olympics. The World Trade Fairs of 1988 makes the first transformation wave; The second was in the early 1990s, when the 1992 Olympic Games relaunched the city, with a multi-billion-dollar building boom. Olympic facilities were developed on an industrial land to face the sea with pride. Barcelona is now undergoing a third wave of transformation. A high technology zone [Diagonal Mar], the Universal Forum of Cultures 2004, a new container port and logistics park are the key developments, constructed on coastal brownfield and reclaimed land.

\subsubsection{Strategy of urban regeneration}

The project involves the transformation of 200 hectares of industrial land and brownfields in the center of Barcelona into an area of the highest urban and environmental quality, creating $3,200,000 \mathrm{~m}^{2}$ for new business, 4,000 for social housing, and $114,000 \mathrm{~m}^{2}$ for new green spaces, with $145,000 \mathrm{~m}^{2}$ new facilities, and 180 million $€$ investment in infrastructure, through establishing a diverse and sustainable urban model with a stronger economy and efficient ecological system.

2.2.3.1 Infrastructure networks In 2004-2007, Barcelona invested over 80 million Euros in the Infrastructure Plan, as shown in table 5.

2.2.3.2 Housing, public spaces The project aims to promote a model of urban diversity, in which tradition and innovation converge. This was achieved through; refurbishment the industrial heritage of the district for new houses and public uses, allows people to live close to their workplace, construct 4,000 new government dwellings, restructuring urban services on the street and underground.

2.2.3.3 Establish magnet projects A series of projects, considered as the "motors" of economic development, with the involvement of the private and public agents, to create clusters of fields of knowledge in science, technology centers, information, communication, medical technology, and energy, that attract the most international projects, leads to establish 925 firms in Barcelona, and turns it into the most dynamic pole for application of knowledge in Europe [12], as shown in table 6. 
Table 5: $\quad$ Barcelona infrastructure plan.

\begin{tabular}{|l|l|}
\hline \multicolumn{1}{|c|}{ Infrastructure } & \multicolumn{1}{c|}{ Work Done } \\
\hline Electricity & - Renovation of the entire network, constructed a new substation \\
\hline Gas Supply & - Existing grid is being extended, up-graded and enhanced \\
\hline Solid Waste & - Construction of several waste collection stations \\
\hline Water & - Existing network is strengthened and improved \\
\hline Communication & - New optic cable telecommunications networks were constructed \\
\hline & - A new underground entrance and exit to the city. \\
& - A coastal ring road connects the national motorway network. \\
& - Metro, tram and bus network link the city along the coastline. \\
& - A new railway connects new transport centre with the Airport. \\
& - High speed railway connects Barcelona with European \\
Transportation & Network. \\
& - Creating an extensive network of bicycle lanes of 29 km. \\
& - Re-urbanized all streets by widening pavements, walkabouts \\
& - Create an octagonal square in every crossroad. \\
- Create hierarchy of streets to reduce noise and pollution. \\
- New parking spaces, loading unloading areas were established. \\
- Traffic control systems and street lighting has being renewed. \\
-Improving safety conditions and visibility.
\end{tabular}

Source: researcher.

Table 6: $\quad$ Barcelona magnet projects.

\begin{tabular}{|l|l|}
\hline Project & \multicolumn{1}{|c|}{ Strategic Objectives } \\
\hline $\begin{array}{l}\text { Media } \\
\text { Cluster }\end{array}$ & $\begin{array}{l}\text { Establish Barcelona Media Park, covering 60,000 } \mathrm{m}^{2} \text { in communications } \\
\text { and audiovisual production; and media sector, such as Television, Radio } \\
\text { channels, and publishing group. }\end{array}$ \\
\hline $\begin{array}{l}\text { ICT } \\
\text { Cluster }\end{array}$ & $\begin{array}{l}\text { Establish Information and Communication Technology including: } \\
\text { Barcelona Digital network to connect Spain with European network, with } \\
\text { firms such as, Yahoo, Casio. }\end{array}$ \\
\hline $\begin{array}{l}\text { Medical } \\
\text { Cluster }\end{array}$ & $\begin{array}{l}\text { Establish biotechnology and biomedical firms, and enhance technology } \\
\text { transfer. }\end{array}$ \\
\hline Energy & Includes firms, energy research centers, eco park for producing energy. \\
\hline $\begin{array}{l}\text { Service } \\
\text { Projects }\end{array}$ & $\begin{array}{l}\text { Support firms in consultancy, companion, management aids, funding, } \\
\text { professional networks and associations, conferences, and research. }\end{array}$ \\
\hline
\end{tabular}

Source: researcher.

2.2.3.4 Urban and equity management Everyday management has take place, in building permits, fees collection, compensation payments, readjustment management, moving and demolitions, agreements of availability of providing land, etc.. Barcelona provides an ideal model of urban management, with inner city renewal, although the physical site is small, which limits urban sprawl because of its topographical constraints restrictions.

2.2.3.5 Waterfront development was achieved through the following [12]

- $\quad$ Redevelopment of the existing port and making extensions to it, fig 3.

- Relocating business and industrial activities, creating a new promenade. 
- Build Olympic village on industrial sites and brownfields near the waterfront.

- Make a reclaim extension to the airport which is a gateway to southern Europe.

- Make extensions to the park and beach, to create unbroken coastal development.

- Develop a marina, parks, new beaches, swimming areas and marine parks.

- Formation of new city central zones with offices commerce and central facilities.

- Create a new area of sea water pools, hotels, and recreational areas.

- Use environmentally friendly transportation on the coast line.

- Constructing commerce offices, auditoriums and exhibitions halls.
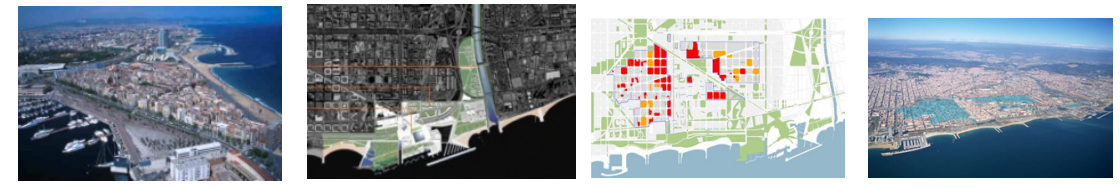

Figure 3: $\quad$ Barcelona waterfront development.

\subsection{Alexandria, Egypt}

Alexandria is one of the oldest Mediterranean cities, founded by Alexander the Great in 331 B.C. It embraced the ancient lighthouse, fig.4, as well as the library. Alexandria today, with its 4 million inhabitants, is Egypt's second largest city. Its borders extend along a $70 \mathrm{~km}$., and covers $2300 \mathrm{~km}^{2}$. It is the home of $40 \%$ of Egypt's industrial establishments. The city is divided into six districts. Behera governorate provides the city with food and labor, while Matruh governorate has immense opportunities for investments in the tourism sector.

\subsubsection{Alexandria urban degradation}

Alexandria faces several challenges: $40 \%$ of its inhabitants live in informal settlements, with limited access to infrastructure and service, high unemployment rate $(20 \%)$, inadequate local services, especially healthcare, education, and youth facilities, poor housing conditions in some areas, pollution of Lake Marriout, absence of open areas, inadequate maintenance funds, and lack of low income housing. These challenges create environmental, social, and economic problems.

\subsubsection{Alexandria regeneration}

Alexandria Development Project [ADP], \$100.00 million enable Alexandria to take advantage of its competitive endowments, better manage local assets, and remove constraints for a private sector-led growth, while ensuring the socioeconomic integration of the poor, improve the living conditions of residents, and prevent further deterioration, figures 4 and 5 . The project aim to:

- Improve economic, infrastructure, and municipal assets.

- Improve investment climate through: reduction of business licensing 
procedures; change property registration process; and expand private sector.

- Redevelopment of Lake Marriout and its surrounding.

- Urban upgrading by integrating the urban poor in the city through improving squatter settlements, increasing access to jobs, and business support services.

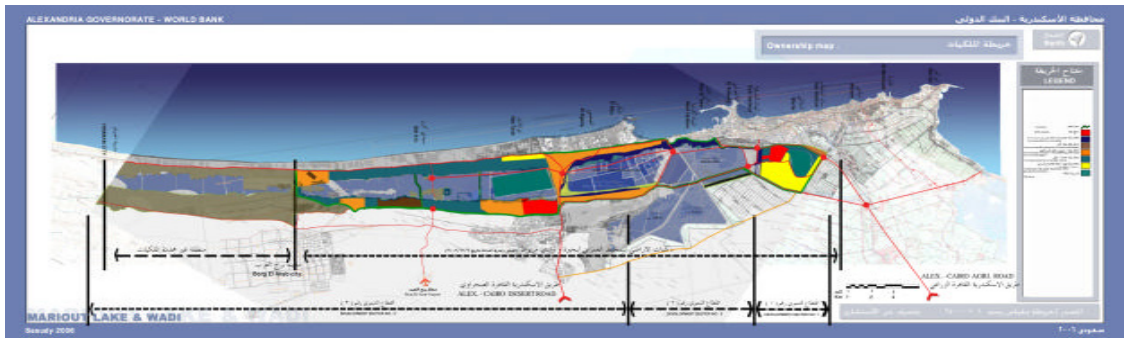

Figure 4: Alexandria urban regeneration plan.

The project starts in 2004. It involves, civil society organizations, private sector, academics, and officials. It has led to a number of new projects that provide economic benefits while focusing on improving the quality of life for all citizens, and apply sustainable development. The project focuses on: Local economic development (LED); Urban upgrading of squatter settlements; and Environmental rehabilitation of Lake Marriout zone and development of its' surrounding.
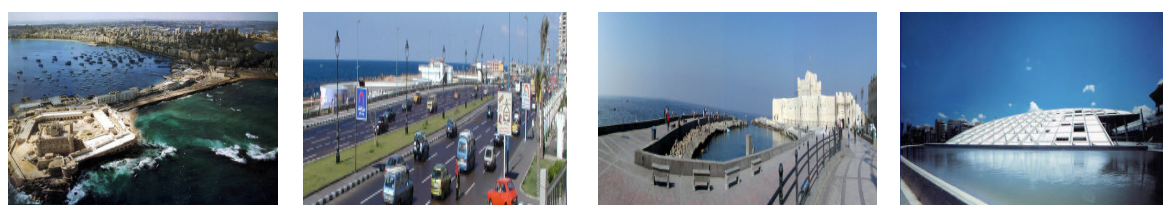

Figure 5: Urban renewal and waterfront development.

\subsubsection{Economic development}

The economic development came up with seven recommended strategic objectives are shown in table 7.

\subsubsection{Urban upgrading}

The 2007-2012 urban plan fig. 4 was approved through the following steps:

- Review of all available data in the district administration.

- List of all the facilities, services, and problems in each district.

- Review of the plans for each service, and coordinating them with the state plans.

- $\quad$ Detailed estimated budget for each district plan from 2007-2012.

- Submitting the budgets to the Local Council.

- Measures for Human Development were identified (e.g. health, education). Three slum areas have been implemented for a total budget of 62 Million LE. 
Table 7: $\quad$ Economic development achievement.

\begin{tabular}{|l|l|}
\hline \multicolumn{1}{|c|}{ Objectives } & \multicolumn{1}{c|}{ Way of Achievement } \\
\hline Job Creation & $\begin{array}{l}\text { Expand investment and trade opportunities; enhance private } \\
\text { sector; and promote work-force development. }\end{array}$ \\
\hline $\begin{array}{l}\text { Investment } \\
\text { Climate }\end{array}$ & $\begin{array}{l}\text { Facilitate business start-ups, land registration procedures; } \\
\text { expanding private sector. }\end{array}$ \\
\hline $\begin{array}{l}\text { Infrastructure } \\
\text { Priority }\end{array}$ & $\begin{array}{l}\text { Improve Lake Marriout; connect city centers with transportation } \\
\text { hubs, and industrial zones with ports. }\end{array}$ \\
\hline $\begin{array}{l}\text { Support } \\
\text { Competitiveness }\end{array}$ & $\begin{array}{l}\text { Implement firm assistance programs to enhance marketing, } \\
\text { management and technical skills. }\end{array}$ \\
\hline Enhance Skills & $\begin{array}{l}\text { Improving educational system; increasing higher education; } \\
\text { develop programs that enhance technical and management skills. }\end{array}$ \\
\hline $\begin{array}{l}\text { Improve } \\
\text { Government } \\
\text { Institutions }\end{array}$ & $\begin{array}{l}\text { Develop managerial systems; document work procedures to } \\
\text { enhance transparency; create data-bases to increase knowledge; } \\
\text { facilitate services and harmonize procedures. }\end{array}$ \\
\hline $\begin{array}{l}\text { Tourism } \\
\text { Development }\end{array}$ & $\begin{array}{l}\text { Develop heritage sights and new tourism; market summer and } \\
\text { family holidays; cruising; adventure travel (yachting, water sports } \\
\text { and archaeology diving), building cultural sites and modern } \\
\text { attractions such as; Bibliotheca Alexandrina, museums, opera } \\
\text { house, and aquarium. }\end{array}$ \\
\hline $\begin{array}{l}\text { Manufacturing } \\
\text { Cluster Model modern industrial park, to support economic } \\
\text { development and attract inward investment at Al Nahda, and } \\
\text { Borg el Arab. }\end{array}$ \\
\hline
\end{tabular}

Source: researcher.

\subsubsection{East Harbour waterfront development}

The Eastern Harbour represents the hub of the city centre and remains the most important physical waterfront feature. Its renovation highlight the importance of the underwater archaeology, creates pedestrian experiences while promoting leisure activities such as bathing, yachting, fishing. The proposal connects economic sustainability with the preservation of traditional activities (e.g. fishing or boat building). New facilities such as the fishing port, yachting marinas, were created. The tourism development focuses on the renovation of the water front while creating Pharos Hotel, fig. 6 at the edge of Silselah and the Forum Convention Centre. The proposal features the environmental theme through the creation of an aquarium, a marine institute and a botanical garden. A new urban development led by an underwater museum opposite to Bibliotheca Alexandrina, exhibits the sunken monuments in the Eastern Harbour, although major obstacles were found in the site; marine pollution and military occupation.
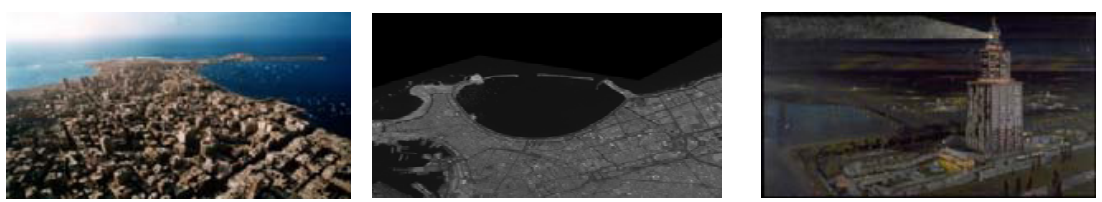

Figure 6: Eastern Harbour of Alexandria with its lighthouse modern project. 


\section{Conclusion}

The paper came to results from urban regeneration in Mediterranean as follows:

- Urban regeneration protects the environment to achieve a balance between social, economic and environment issues. Improving the quality of urban areas means achieving: citizen's approval, encouragement of new enterprises [8].

- Urban regeneration in Genoa's involves restoration of historical centre and the port area. Genoa has completely transformed its image without losing any of its vibrancy. The goals urban regeneration project have been; rehabilitation of urban structures; improve the environment, the quality of life of inhabitants; preserve valuable and unique buildings; restructure economic activities.

The most important lesson from Genoa's is that the process of urban regeneration is the result of an integrated approach, between urban interventions, cultural policies, tradition and innovation. The participation of the private sector was very important, and meets the needs of the community.

Table 8: $\quad$ Evaluation of Mediterranean regeneration case studies.

\begin{tabular}{|l|c|c|c|}
\hline Criteria & Genoa & Barcelona & Alexandria \\
\hline Secure environment & & & \\
\hline Waterfront integrates with urban fabric & & & \\
\hline Preserve historic identity & & & \\
\hline Urban and equity management & & & \\
\hline Transfer of waterfront old industrial areas & & & \\
\hline Creating new centers and city image & & & \\
\hline Improve living conditions & & & \\
\hline Political support and commitment & & & \\
\hline Renewal of urban economy & & & \\
\hline Mixed use development & & & \\
\hline Planning in public private partnerships & & & \\
\hline Regeneration as long term projects & & & \\
\hline Upgrade transportation Systems & & & \\
\hline Develop pedestrian accessibility & & & \\
\hline Tourist and entertainment areas development & & & \\
\hline Creating new city spaces & & & \\
\hline Ports development & & & \\
\hline Upgrading historic city centre & & & \\
\hline Renewal of infrastructures network & & & \\
\hline Upgrade slum areas & & & \\
\hline Establish magnet projects & & & \\
\hline Improve investment climate & & \\
\hline Source: researcher. & & \\
\hline
\end{tabular}

Source: researcher.

Excellent $\bigcirc$ Moderate $\bullet$ Not Available $\bigcirc$ 
- Barcelona was influenced by organising the Olympic Games. The renovation have been realised with public economic contribution, participation of the private sector, social and institutional settings, as well as strategy were important.

- While Alexandria still in the beginning of its regeneration process, with a little emphasis on the local economy dynamics, institutional/financial dimensions; little private sector participation; and non - participatory in planning decision. It serves as a pilot case to test selected strategic reforms that remove constraints to investment climate, and strengthen government's urban management.

\section{References}

[1] ElMenchawy, A., Associate professor, urban regeneration in Mediterranean cities, an integrated urban development of brownfield sites, Cephalonia, Greece, 2008.

[2] Gabrielli B., L'idea del futuro di Genova, Info RUM n. 7, pp. 45. Giddens, A., "The Consequences of Modernity", Polity Press, Cambridge, 2000.

[3] Lichfield D., The context of Urban Regeneration, Sage Publications Ltd., 2000 .

[4] Urbanistica, no. 126, January-April 2005.

[5] Alcozer F., A Journey Among the Cities, in " + Città", Alinea Genova, 2004.

[6] Bisio, L., Bobbio, R., "The Pulsar Effect in Genoa; form big events to urban strategy", 2003.

[7] Ferlenga, A., The Life of Cities, in “ + Città”, Alinea Editrice, Genova, 2004.

[8] Gabrielli, B., eds "Genoa, a strategic plan for effectiveness and its result", 2005.

[9] 38th International ISoCaRP Congress, The Hague: ISoCaRP, Athens, 2002.

[10] Marson, A. "New Genoa", CT. City Issues, no. one, 2005.

[11] McCarthy, J., "The regeneration of urban waterfronts", Vol. 5. No. 2, 1998.

[12] Monclus, F.J. "The Barcelona model: From reconstruction to strategic urban projects, Planning Perspectives, Vol. 18. No. 4, 2003.

[13] Olmo C, The dilemmas of regeneration, in “+Cities", Alinea Genova, Palmer R., Cultural Holistic Planning, Reference Dialogue of the Forum BCN 2004.

[14] Portas N, Regeneration and Urban Project, in "+ Città", Alinea Genova, 2004.

[15] Roberto Bobbio, Re-shaping Spaces for a New Economy, 41st ISoCaRP Congress, 2005.

[16] Rossana Galdini, "Land Use and Water Management in a Sustainable Network Society", 45th Congress of the European Regional Science Association, 2005.

[17] Cityports, www.cityports.net 